\title{
Disaster preparedness for metro projects: a social-cognitive perspective of Pakistan
}

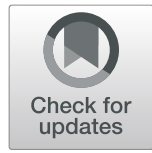

Muhammad Abid ${ }^{1,2}$, Muhammad Umer ${ }^{3^{*}}$ (D), Ahsen Maqsoom ${ }^{4}$ and Zaineb Abid ${ }^{5}$

\begin{abstract}
During the last decade, 2.4 billion individuals, the majority of which were residing in low economic growth countries, became victim of global disasters. As economic growth is correlated with the resilience of a nation against a disaster, therefore developing and underdeveloped nations significantly face higher magnitude of losses. With Pakistan being a developing country, the present study takes into account the most recently accomplished mega project of METROBUS service that is currently operational in the twin metropolitan cities of Pakistan i.e. Islamabad and Rawalpindi to study the pre and post development perspectives of project in terms of the hazard perception, prospect disaster threats it poses towards the society in case of major seismic activity and the magnitude of disaster preparedness associated to the potential hazardous circumstances as result of seismic event occurrence. Statistical evaluations for the current study were conducted utilizing the SmartPLS 3.0, being based upon the information collected through 336 self-supervised surveyed responses. The results of the current study indicated, the respondents to be highly in favor of the commute service project, but at the same time, they highlighted the concerns regarding socio-economic adversities faced during the project development phases as well as after its completion. Further, the respondents expressed major reservations regarding the disaster management measures taken by the potential stakeholders of the project. Despite the fact that most of the respondents were well educated, the lack of awareness regarding preparedness against any possible project related disastrous situation, was observed. To mitigate the potential disaster losses associated to the project, respondents suggested that the national authorities should proactively provide awareness to the public and assure the availability of all necessary facilities, in case of any hazardous situation; seismic in particular. Considering the practical implications, the current study may be useful for other developing countries, which too faced similar concerns during development of comparable megaprojects and share similar environmental conditions.
\end{abstract}

Keywords: METROBUS, Disaster, Pakistan, Seismic, Earthquakes, Surveys

\section{Introduction}

Disasters, natural or man-made result in significant damages in terms of environmental, material, economic or a widespread human loss. Most disaster occurrences are regarded as man-made that occur due to lack of preventive measures or improper disaster management, attributed to the infrastructure developed by humans. This usually results in hazards that may sometimes even instigate a secondary disaster as well (Korver 1986; Perry

\footnotetext{
* Correspondence: umer_stu@ciitwah.edu.pk

${ }^{3}$ Department of Management Science, COMSATS Institute of Information

Technology, Wah Cantt, Pakistan

Full list of author information is available at the end of the article
}

2007); (Blaikie et al. 2014; Montz et al. 2017; Smith 2013); (Paton and Johnston 2017);(Blaikie et al. 2014; UNISDR C 2015); (Debarati Guha-Sapir et al. 2017).

During the past few decades, the rate of geophysical disasters has remained more or less constant, yet the frequency of disaster occurrences has raised to more than twice than they were between years 1980-1989. Global disasters occurrences averaged 246 for the period of 1994-2003, but these figures increased 10 folds and more within the next 10 years, valuing a count of 369 climatic irregularities per annum (Guha-Sapir et al. 2012). Of all types of natural disasters, earthquakes have been responsible for most deaths with 0.75 million lives 
lost, between 1994 and 2003 (Jonkman 2005; Keim 2008; UNISDR C 2015). It has also been observed that the countries with lower income capacity are the ones most affected by the natural disasters. Death toll during disasters in Asia, Africa, America, Oceania and Europe got recorded as $62.7 \%, 28.0 \%, 7 \%, 2.2 \%$ and $0.21 \%$ respectively. This concludes that the regions with lack of preparedness against the natural calamities suffer the most (Debarati Guha-Sapir et al. 2017; UNISDR C 2015).

Pakistan being a developing country lies in the list of nations with middle-lower income capacity. This poses a great challenge to cope up with disasters and related adversities (Razzaq et al. 2018). In the light of past occurrences, Pakistan has faced major catastrophes as a result of earthquakes and floods. Pakistan is located in the continent Asia which got hit by a total of 2778 natural calamities over period of 20 years, affecting 3.8 billion individuals and resulting in approximately 841, 000 fatalities (1994-2013) (Guha-Sapir et al. 2004; Kirsch et al. 2012; Wahlstrom and Guha-Sapir 2015). In broader perspective, Asia got affected by $48 \%$ of the total global disasters in 2014 (Guha-Sapir and Ph 2015); which increased to $62.7 \%$ in 2015 ; resulting in $86 \%$ people being affected and $85 \%$ of the fatalities.

As far as the disaster profiling goes, Pakistan is listed among the top 10 countries in the world that faces disastrous instances over the year and higher disaster mortality count. Among these 10 countries, 6 are listed as the ones with either low or middle-low income and 5 are located in Asia alone (Busby et al. 2018; Khan 2010). Pakistan in specific incurs a loss of more than $\$ 800$ million per annum, because of the absence of effective disaster management system (Khan and Khan 2008). The country primarily has been a target of seismic activities with over 60 major earthquakes on record; the worst of which occurred in 2005, resulting the nation a loss of 87 , 350 lives, 3.5 million people displaced and $\$ 5.2$ billion economically (Durrani et al. 2005; Rossetto and Peiris 2009).

In terms of demographics, Pakistan itself is the 6th most populous country in the world which over time has required development of infrastructure to sustain its citizens (Plane 2017). The budget allocation for year 2017-2018 had only $\$ 6.244$ billion out of $\$ 29.66$ billion allocated to infrastructure development (Pakistan Go 2017). This signifies the fact that the primary stakeholders of the infrastructure development need to play a pivotal role in assuring implementation of efficient and effective security measures to prevent disasters leading to more disasters. As it has already been discussed that development of infrastructure with lack of proactive safety measures in densely populated areas can be the primary cause of turning a natural hazard into disaster; thus, it requires the related authorities to identify the already existent safety lapses in related projects and rectify them accordingly (Lim and Yang 2008; Toh et al. 2017; Williams et al. 2018). To comprehend the sensitivity of the seismic disasters in Pakistan and further relate these to the associated adversities, the major seismic occurrences within the country up until year 2018 are depicted in Table 1(Ahmed 2018; Akbar 2016; Kaneda et al. 2008; Sasoli 2017; Syed Ali Shah et al. 2018).

Keeping in view of the seismic disasters across the country over the years, major financial losses in terms of infrastructural damages and disrupted business activities, as well as life losses have been incurred as a result of poor hazard planning and lack of available resources (Idrees and Khan 2018; Shahbaz 2019). In specific, of all the major seismic events listed above $33.33 \%$ of them have affected Rawalpindi \& Islamabad. Moreover, considering the presented information it can be observed that almost each of these events have caused substantial loss to the materials and lives of the locals. Of the mentioned events, the most destructive and of recent incurrence is the one of year 2005, that along with northern regions of Pakistan substantially effected Islamabad and Rawalpindi as well.. The regarding seismic activity was attributed with a magnitude of $7.6 \mathrm{M}_{\mathrm{w}}$, which led to death toll of 87,350 and left 4,000,000 people rendered homeless (Sana et al. 2019). Therefore, any future seismic occurrence within the twin cities is probable to lead to potential damages, yet again. Especially if the responsible authorities do not induce proactive safety measures in the prospect development of the infrastructure and do not equip the public with necessary knowledge and facilities required to manage through hazardous events (Parajuli 2020). This situation is very much comparable to Nepal, Bangladesh and India as countries that have been facing disastrous situations over the past decades and incurred extensive damages as result of incapacitated disaster management systems. To mitigate the circumstances these nations have been adapting and evolving upon "Disaster Risk Reduction" (DRR) practices to enhance the early warning systems and timely deploy the safety measures to minimize the possible damages (Parajuli 2020). But the implementation of these practices on the governmental alone has not brought any significant improvement in the past, rather the opposite has been the true. To overcome the gap and the effective implementation of the devised disaster management practices, it has been commended to educate the public in regard to managing through disaster events. As the said approach of "Citizen Disaster Science Education" (CDSE) has proved itself to be effective in enabling the individuals to make educated decision when face by a hazardous situation and overcome the unfavorable circumstances as much as possible (Tuladhar et al. 2015). Considering which, the current study is conducted on the recently accomplished mega project of METROBUS 
Table 1 Major seismic activity timeline of Pakistan

\begin{tabular}{|c|c|c|c|c|c|}
\hline Index & Date & Location & $\begin{array}{l}\text { Occurrence/ } \\
\text { Magnitude }\end{array}$ & Casualties & $\begin{array}{l}\text { Infrastructure } \\
\text { damage }\end{array}$ \\
\hline 1. & December 28, 1947 & Hunza & $w 6.2 M$ & $\begin{array}{l}\text { Death Count: } 5300 \text {, } \\
\text { Injured: } 17,000\end{array}$ & Yes \\
\hline 2. & September 10, 1971 & Gilgit & - & Death Count: 100 & 1000 Building Units \\
\hline 3. & January 1, 1972 & Rawalpindi, Islamabad, Abbottabad, Lahore \& Sialkot & Moderate Tremors & 0 & Yes \\
\hline 4. & June 30, 1974 & Rawalpindi, Peshawar \& Multan & Severe Tremors & Death Count: 4 & Yes \\
\hline 5. & December 28, 1974 & Pattan, Hazara, Hunza \& Swat & w7.4 M & $\begin{array}{l}\text { Death Count: } 5300 \text {, } \\
\text { Injured: } 17,000\end{array}$ & 4400 Building Units \\
\hline 6. & December 31, 1983 & Gilgit Baltistan (Partial Region) & w.2 M & $\begin{array}{l}\text { Death Count: 26, } \\
\text { Injuries: } 483\end{array}$ & Yes \\
\hline 7. & May 31, 1995 & $\begin{array}{l}\text { Mastung, Mongechar, Dera Murad Jamali \& Chatar } \\
\text { Tehsil }\end{array}$ & w5.2 M & Injured: 5 & Yes \\
\hline 8. & May 20, 1992 & Kohat Division & $w^{6} \mathrm{M}$ & $\begin{array}{l}\text { Death Count: } 36 \text {, } \\
\text { Injuries: } 100\end{array}$ & Yes \\
\hline 9. & February 28, 1997 & $\begin{array}{l}\text { Rawalpindi, Islamabad, Multan, Muzaffargarh, Dera } \\
\text { Ghazi Khan, Shuj-Abad, Leiah, Vehari, Sukkur, Rohri, } \\
\text { Ghotki, Daharki, Ubaro, Liaquat-Pur, Jacob-Abad, } \\
\text { Kandh-Kot, Dadu, Larkana, Warah, Shahdadkot, } \\
\text { Kambar, Bolan, Jhal Magsi, Usta Mohammad, Sibi, } \\
\text { Bugti and Marri Tribal Regions, Mithri, Koh-I-Suleiman } \\
\text { Range, Chaman, Qila Abdullah, Qila Saifullah, Pishin, } \\
\text { Ziarat, Mastung, Kalat, Sorab \& Khuzdar }\end{array}$ & w7.2 M & Death Count: 100 & Yes \\
\hline 10. & March 20, 1997 & Salarzai & $w 4.5 \mathrm{M}$ & Death Count: 10 & Yes \\
\hline 11. & January 26, 2001 & Sindh (Entire Region) & w6.5 M & Death Count: 15, Injured: 108 & Yes \\
\hline 12. & October 3, 2002 & Northern Areas (Partial Region) & w5.1 M & $\begin{array}{l}\text { Death Count: 17, Injured: 30, } \\
\text { Rendered Homeless: } 1500\end{array}$ & Yes \\
\hline 13. & October 22, 2002 & Astore Valley & $w^{5.5} \mathrm{M}$ & Death Count: 23 & Yes \\
\hline 14. & February 14, 2004 & $\begin{array}{l}\text { Northern Areas (Partial Region) \& Khyber } \\
\text { (Entire Region) Pakhtunkhwa }\end{array}$ & w, $5.5 \mathrm{M}_{\mathrm{w}} 5.7 \mathrm{M}$ & Death Count: 24, Injured: 40 & Yes \\
\hline 15. & October 8, 2005 & Northern Areas (Partial Region) \& Kashmir & w7.6 M & $\begin{array}{l}\text { Death Count: } 87,350 \text {, } \\
\text { Injured: } 200,000+, \text { Rendered } \\
\text { Homeless: } 4,000,000\end{array}$ & Yes \\
\hline 16. & October 28, 2008 & Quetta & w6.4 M & Death Count: 216, Injured: 370 & Yes \\
\hline 17. & January 18, 2011 & Balochistan (Partial Region) & w.2 M & Death Count: 2 & 200 Building Units \\
\hline 18. & January 20, 2011 & Quetta & w7.4 M & 0 & 200 Building Units \\
\hline 19. & April 16, 2013 & Quetta & w7.9 M & Death Count: 34, Injured: 80 & 10,000 Building Units \\
\hline 20. & September 24, 2013 & Awaran District & w7.7 M & Death Count: 825, Injured: 700 & $1000+$ Building Units \\
\hline 21. & September 28, 2013 & Awaran District & w6.8 M & Death Count: 400 & Yes \\
\hline 22. & May 8, 2014 & Sindh (Partial Region) & w.5 M & Death Count: 2, Injured: 50 & Yes \\
\hline 23. & October 26, 2015 & $\begin{array}{l}\text { Rawalpindi, Islamabad \& Northern Areas } \\
\text { (Partial Region) }\end{array}$ & w7.7 M & Death Count: 399, Injured: 2536 & Yes \\
\hline 24. & December 25, 2015 & Khyber Pakhtunkhwa (Partial Region) & w6.3 M & Death Count: 4, Injured: 100 & Yes \\
\hline 25. & April 10, 2016 & $\begin{array}{l}\text { Punjab (Partial Region) \& Khyber Pakhtunkhwa } \\
\text { (Partial Region) }\end{array}$ & w7.1 M & Death Count: 6, Injured: 27 & 20 Building Units \\
\hline 26. & February 8, 2017 & Gwadar, Makran \& Pasni & w6.3 M & 0 & Nil \\
\hline 27. & January 31, 2018 & $\begin{array}{l}\text { Islamabad, Peshawar, Charsadda, Murree, Sargodha, } \\
\text { Shangla, Haripur, Gujranwala, Lahore, Quetta, \& } \\
\text { Karachi }\end{array}$ & w6.1 M & Injured: 11 & Yes \\
\hline
\end{tabular}

Source: (Ahmed 2018; Akbar 2016; Kaneda et al. 2008; Sasoli 2017; Syed Ali Shah et al. 2018)

service, which has gathered a lot of appraise for its service as well as serious amount of criticism over numerous safety and quality shortcomings attributed to it. The METROBUS project was started on April 23, 2014 and was completed on March 27, 2015 with a budget of
$\$ 310$ million. It is a $22.5 \mathrm{~km}$ rapid transit track that operates along 24 stations between twin metropolitan cities of Pakistan, i.e. Rawalpindi and Islamabad. Currently the project has a fleet of $68(18 \mathrm{~m})$ long high-floor articulated buses, facilitating a daily ridership of 150,000 
individuals between the two cities. The project contains various stations that have underground passages leading to the platform while a significant portion of the service tracks are elevated that pass through the city with the traffic underneath and occupants residing on the surroundings. Both of the aspects of the project are vulnerable to the prospect seismic disaster, as the project has already faced deterioration as result of monsoon rains and physical damages as result of periodic earthquakes of lower and moderate magnitude (Desk 2015; Pakistan Go 2014; Zaafir 2017). Considering which, the project poses a potential threat to the areas with nearby population and infrastructure.

During the construction of the project, a reasonable number of people were affected due to displacement, business failures, travel difficulties and many other factors. Due to these reasons, this present study takes into account the pre and post-construction scenarios of METROBUS project in Rawalpindi-Islamabad, Pakistan that have impacted and may impact the residents in future. Further, it investigates the social perception of a disaster and the public readiness towards any such prospect seismic disaster event (Parajuli 2020; Tuladhar et al. 2015). Taking into account, the aforementioned aspects of the current study following potential statements were hypothesized:
H1: Disaster Preparedness (Individual Level) will significantly impact the Agreeableness Towards Project. H2: Disaster Preparedness (State Level) will significantly impact the Agreeableness Towards Project.

H3: Post Completion Adversities will significantly impact the Agreeableness Towards Project.

H4: Post Completion Perception will significantly impact the Agreeableness Towards Project.

H5: Project Utilization will significantly impact the Agreeableness Towards Project.

Considering the necessity of the current study, it must be taken into account that the infrastructural initiative such as Rawalpindi-Islamabad METRO project is the second one of its kind that has ever been accomplished in Pakistan. With being located in Rawalpindi and Islamabad, METRO project faces potential seismic threat, as the cities are marked as areas with moderate to severe seismic activity (See Fig. 1). This demands evidence-based study, to gauge the possible effects of the infrastructure development of such projects in social terms as well as the highlight necessity of precautionary measures required in case of any calamity. Hence, the outcomes of this study are probable to serve as a potential guideline for the prospect projects within the country, or countries that share relatable development approach as well as environmental conditions as Pakistan.

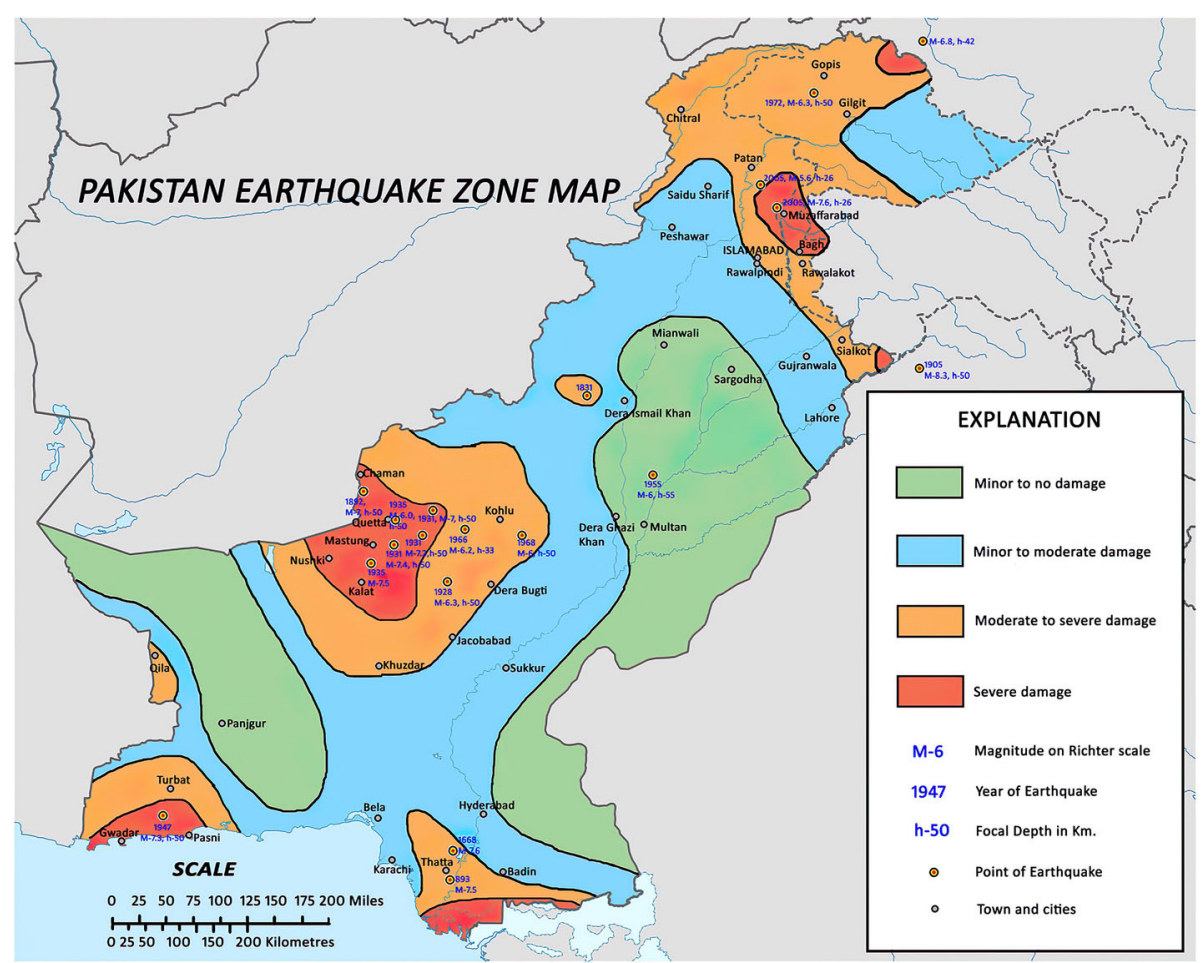

Fig. 1 Seismic hazard map of Pakistan (Center GD 2017) 


\section{Methodology}

A survey-based approach was adopted to collect the responses from the individuals residing in the twin cities of Pakistan i.e. Rawalpindi and Islamabad, with a population count of 3.12 million (Ringle et al. 2017). Justified to which, a sample of 267 individuals was statistically considered enough to generalize the results of the study on broader perspective, while keeping in view of the 95\% confidence interval (Hox et al. 2017; Lane and Hennes 2018). Questionnaire was designed to focus on primary concerns of the citizens in terms of pre and post-construction of the METROBUS project and their understanding and preparedness towards a seismic disaster scenario (BiBi et al. 2015; Mansoor et al. 2016). Questionnaire was examined by the academic professionals, finalized for 37 questions, and was then proceeded for the pilot testing conducted upon 84 participants. The positive outcome of process justified the validation of questionnaire in terms of further dissemination among the general audience. Questionnaire included 7 unique sections i.e. demographics (3 questions), project utilization (2 questions), post-completion adversities (4 questions), disaster preparedness at individual level (9 questions), disaster preparedness at state level (5 questions), prospect METROBUS disaster management perception (9 questions), and agreeableness towards the project (5 questions). The responses were recorded on 5-Point Likert scale. The values on the scale ranged from ' 1 ' referring to "Strongly Disagree/Very Unlikely" up-to ' 5 ' on the scale referring to "Strongly Agree/Very Likely" (Awang et al. 2016).

The respondents were a mix of both the residents as well as the owners of the commercial property that was operational alongside the METROBUS track. The information collection process primarily targeted the areas with dense population or owned business infrastructure in the vicinity. Further, the individuals residing in the surrounding areas that were well familiar with the project were also taken into account. (See Fig. 2).

The survey process was self-supervised which enabled the collection of accurate responses. Since all the respondents were situated within the project's vicinity and were the primary affectees of the pre and post completion of the project and most aware of the project. As twin cities have a diverse population with individuals from every part of the country, survey helped in more demographic opinions. In addition, responses of physically handicapped residents that were almost $<1 \%$ were also included in the survey. A total of 336 responses were collected and processed for statistical manipulations.

\section{Analysis \& results}

The information attained from the respondents was evaluated in terms of quality as well as relational criterions while utilizing the SmartPLS 3.0 (Ringle et al. 2017).

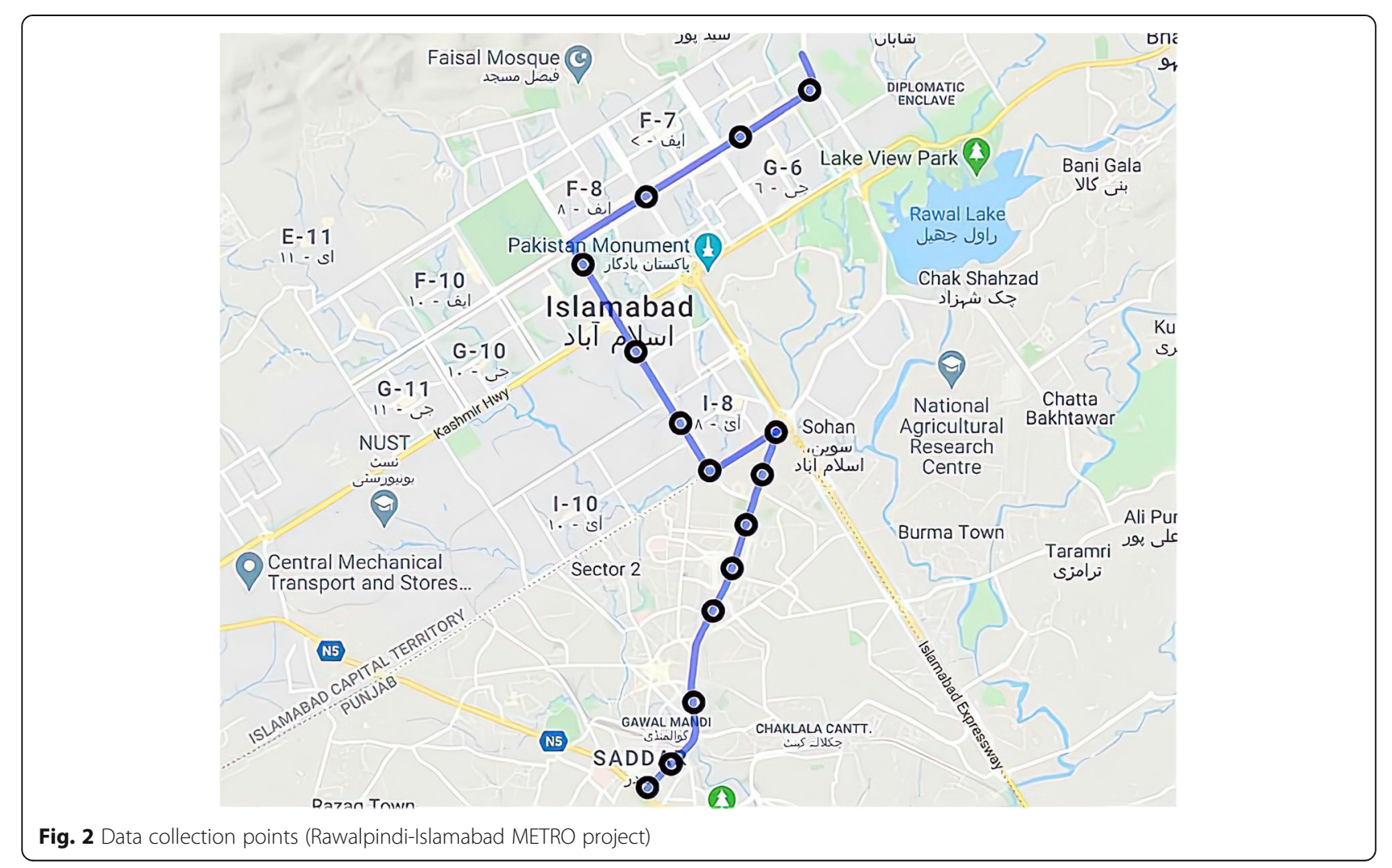


Keeping in view of the research model, the survey instrument was first tested for its quality in terms of reliability and validity. Followed to which, the attained information was tested in terms of data fitness criterions. Lastly, the prior mentioned hypothesized relationships were tested, while considering the attributed significance. This approach further led to the acceptance and rejection of the proposed relations.

\section{Demographics}

While profiling the targeted respondents, it is observed that almost $45 \%$ respondents were occupants of residential/commercial infrastructure situated right along METROBUS track; whereas rest of the respondents were residing in the areas nearby; not under direct influence of the project. Age wise, $21 \%$ of the respondents were below 20 years; $75 \%$ were between $20 \sim 30$ years and $5 \%$ were of 31 years and above. In terms of academic qualification, $18 \%$ of the respondents were intermediate or below, whereas $70 \%$ were with graduation and $12 \%$ were with master degree and above (Table 2). The majority of the respondents with strong academic backgrounds projected an educated response towards the study being conducted.

The attained information was further evaluated in terms of criterions of structural equation modeling (SEM). To begin with, the survey instrument was tested for its reliability in terms of the criterion of Cronbach's Alpha (Gliem and Gliem 2003); which suggests, that for a research instrument to be valid the value of the referred criterion should be above 0.70. All the components associated to the variables under study were found reliable (Table 3).

Table 2 Demographics - responses vs age group and education level

\begin{tabular}{ll}
\hline Age & Responses \\
Below 20 Years & 73 \\
$20-30$ Years & 251 \\
$30-40$ Years & 8 \\
$40-50$ Years & 3 \\
50 Years \& Above & 1 \\
Grand Total & 336 \\
Educational Level & Responses \\
Matric or Below & 2 \\
Intermediate & 59 \\
Graduation & 236 \\
Masters & 36 \\
PhD. & 2 \\
Post-Doc. & 1 \\
Grand Total & 336 \\
\hline
\end{tabular}

Table 3 Instrument's reliability

\begin{tabular}{lll}
\hline Variables & $\begin{array}{l}\text { Cronbach's } \\
\text { alpha }\end{array}$ & $\begin{array}{l}\text { Composite } \\
\text { reliability }\end{array}$ \\
\hline Agreeableness Towards Project & 0.749 & 0.721 \\
Disaster Preparedness Individual Level & 0.712 & 0.701 \\
Disaster Preparedness State Level & 0.730 & 0.753 \\
Post Completion Adversities & 0.789 & 0.709 \\
Post Completion Perception & 0.772 & 0.728 \\
Project Utilization & 0.847 & 0.842 \\
\hline
\end{tabular}

Further, the validity of the opted research instrument was evaluated for its convergent as well as discriminant nature. The convergence of a research instrument is the magnitude of similarity between the research instrument of a respective variable as well as its related components. The more related the components are the more valid a research instrument is considered to measure the attributed phenomena (Cable and DeRue 2002). The convergent validity is measured in terms of Average Variance Extracted (AVE). As per the criterion, the respective value of AVE associated to a variable should be above 0.5 , for it to be convergently valid (Hair et al. 2011). All the variables and their associated component were found to be convergently valid (Table 4).

The discriminant aspect of validity suggests that the variable and its components should be unique in nature and should not relate to the components of other variables. To evaluate the discriminant nature of a research instrument, the criterion of Fornell-Larcker is utilized (Fornell and Larcker 1981). According to which, the correlative value of the regarding validity criterion for the regarding variable with itself should be more than the correlative value in relation to other variables under study (Hair et al. 2011; Wong 2013). Keeping, that in view all the variables fulfilled the validity criterion (Table 5 ).

In continuum to which, another criterion to evaluate the discriminant nature of validity associated to the opted research instrument is the cross loadings. Cross loadings are comparatively a better-quality criterion in comparison to the one discussed prior, because instead of depicting the cumulative effect of a variable as whole, the unique values for each research question are

Table 4 Instrument's convergent validity

\begin{tabular}{ll}
\hline Variables & $\begin{array}{l}\text { Average Variance } \\
\text { Extracted (AVE) }\end{array}$ \\
\hline Agreeableness Towards Project & 0.722 \\
Disaster Preparedness Individual Level & 0.652 \\
Disaster Preparedness State Level & 0.841 \\
Post Completion Adversities & 0.760 \\
Post Completion Perception & 0.677 \\
Project Utilization & 0.964 \\
\hline
\end{tabular}


Table 5 Instrument's discriminant validity (Fornell Larcker)

\begin{tabular}{|c|c|c|c|c|c|c|}
\hline Variables & $\begin{array}{l}\text { Agreeableness } \\
\text { towards project }\end{array}$ & $\begin{array}{l}\text { Disaster preparedness } \\
\text { individual level }\end{array}$ & $\begin{array}{l}\text { Disaster } \\
\text { preparedness } \\
\text { state level }\end{array}$ & $\begin{array}{l}\text { Post completion } \\
\text { adversities }\end{array}$ & $\begin{array}{l}\text { Post completion } \\
\text { perception }\end{array}$ & $\begin{array}{l}\text { Project } \\
\text { utilization }\end{array}$ \\
\hline $\begin{array}{l}\text { Agreeableness Towards } \\
\text { Project }\end{array}$ & 0.471 & & & & & \\
\hline $\begin{array}{l}\text { Disaster Preparedness } \\
\text { Individual Level }\end{array}$ & 0.370 & 0.390 & & & & \\
\hline $\begin{array}{l}\text { Disaster Preparedness } \\
\text { State Level }\end{array}$ & 0.207 & 0.243 & 0.584 & & & \\
\hline $\begin{array}{l}\text { Post Completion } \\
\text { Adversities }\end{array}$ & 0.251 & 0.281 & 0.109 & 0.510 & & \\
\hline $\begin{array}{l}\text { Post Completion } \\
\text { Perception }\end{array}$ & 0.277 & 0.295 & 0.326 & 0.273 & 0.420 & \\
\hline Project Utilization & 0.135 & 0.056 & 0.068 & 0.014 & 0.139 & 0.681 \\
\hline
\end{tabular}

evaluated for quality check. According to the criterion of cross loadings, for a variable to be discriminately valid the correlative values of a given variable in relation to its respective components should be higher in comparison to the correlative values of other variables under study in relation to the prior considered components (Hair et al. 2011). Keeping that in view the respective variables were found to be discriminately valid (Table 6).

Lastly, the most accurate criterion to test for discriminant validity taken into consideration is HeterotraitMonotrait Ratio (HTMT) with the precision range of 97\%-99\% (Ab Hamid et al. 2017), in contrast to the precision range of Fornell-Larker criterion that is valued between $0.00 \%-20.82 \%$. As per the HTMT criterion, for a variable and its respective components to be valid, the correlative value of any given variable with itself should be below 0.90 (Ab Hamid et al. 2017). Refereed to which, the calculated discriminately valid variables are summarized in Table 7.

Variance Inflation Factor (VIF) tests for the magnitude of collinearity existent between the variables and their associated components, while considering the dataset attained from the targeted population. For a variable to fulfill the multicollinearity criterion the values associated to its components should be below 5 (Hair et al. 2011). Keeping that in view, the variables in terms of associated information were found to fulfill the multicollinearity criterion (Table 8).

The variable and their respective components were further tested and observed fit based on the correlation factors calculated above 0.70 (Afthanorhan et al. 2016; Afthanorhan 2013) (Table 9).

Regarding conformance of quality criterions of the measurement model, the respective structural model was evaluated in terms of effect of observed variables upon the associated latent variables and their respective significance. The magnitude of effect is observed in terms of path coefficient values that are ranged between \pm 1 , which shows the positive and negative inclination of the effect between the variables under study (Hair Jr et al. 2016). Keeping that in view, in comparison to other factors the post completion adversities were found to have highest effect upon the agreeableness towards the project, with being valued at 0.424 . Moreover, the respective relationships were justified for their significance in terms of the $(P)$ value attributed to the measured effects. In alignment to which, all effects were found significant (Table 10).

Moreover, the influence associated to the respective variables was evaluated in term of the effect size. The respective effect was determined in terms of $f^{2}$ value, which if ranged from 0.02-0.14 represents a small effect, or if ranged between $0.15-0.35$ represents medium effect, and if ranged 0.36 or above represents large effect (Hair Jr et al. 2016; Ringle et al. 2017). Referred to which, disaster preparedness state level, post completion adversities and post completion perception were found to have medium effect size. While disaster preparedness individual level and project utilization were observed to have small effect size (Table 11).

Lastly, the cumulative effect of exogenous variables to explain the variation in the endogenous variable in the study was explained in terms of $r^{2}$. The regarding vale of which variates from 0 to 1 (Di Bucchianico 2008). Referred to which, the independent variables in the opted structural model were able to explain the magnitude of variance in the agreeableness towards the project by $45.2 \%$ (Table 12).

Considering the evaluations of measurement as well as structural model, all the quality and relational criterions were fulfilled. Therefore, the hypothesized relationships were considered accepted (See Table 13).

\section{Discussion}

Keeping in view of the statistical evaluation, all the aspects taken into consideration were found to be a significant contributor towards the overall agreeableness towards the 
Table 6 Instrument's discriminant validity (cross loadings)

\begin{tabular}{|c|c|c|c|c|c|c|}
\hline Items & $\begin{array}{l}\text { Agreeableness } \\
\text { towards project }\end{array}$ & $\begin{array}{l}\text { Disaster preparedness } \\
\text { individual level }\end{array}$ & $\begin{array}{l}\text { Disaster preparedness } \\
\text { state level }\end{array}$ & $\begin{array}{l}\text { Post completion } \\
\text { adversities }\end{array}$ & $\begin{array}{l}\text { Post completion } \\
\text { perception }\end{array}$ & $\begin{array}{l}\text { Project } \\
\text { utilization }\end{array}$ \\
\hline AP1 & 0.304 & 0.136 & -0.089 & 0.107 & -0.092 & 0.116 \\
\hline AP2 & 0.321 & 0.129 & -0.033 & 0.147 & -0.075 & 0.001 \\
\hline AP3 & 0.178 & -0.152 & 0.172 & 0.063 & 0.151 & 0.069 \\
\hline AP4 & 0.206 & 0.107 & -0.066 & 0.146 & -0.039 & -0.066 \\
\hline AP5 & 0.930 & 0.319 & -0.177 & 0.537 & -0.476 & 0.143 \\
\hline DPI2 & -0.144 & 0.712 & 0.649 & -0.025 & 0.209 & -0.081 \\
\hline DPI1 & 0.082 & 0.185 & -0.010 & 0.060 & -0.109 & -0.003 \\
\hline DPI2 & 0.177 & 0.524 & -0.079 & 0.088 & -0.097 & 0.051 \\
\hline DPI3 & 0.262 & 0.635 & -0.145 & 0.261 & -0.155 & -0.070 \\
\hline DPI4 & -0.230 & 0.650 & 0.202 & -0.201 & 0.265 & 0.093 \\
\hline DPI5 & -0.109 & 0.335 & 0.099 & -0.076 & 0.103 & 0.083 \\
\hline DPI6 & 0.019 & 0.199 & 0.088 & 0.003 & 0.054 & 0.009 \\
\hline DPI7 & -0.013 & 0.113 & 0.028 & 0.093 & -0.023 & 0.011 \\
\hline DPI8 & -0.077 & 0.314 & 0.114 & -0.002 & 0.084 & 0.015 \\
\hline DPI9 & 0.061 & 0.233 & -0.026 & -0.072 & -0.010 & 0.221 \\
\hline DPS1 & -0.103 & -0.096 & 0.628 & -0.056 & 0.270 & -0.099 \\
\hline DPS3 & -0.111 & -0.121 & 0.596 & -0.047 & 0.255 & -0.010 \\
\hline DPS4 & -0.065 & -0.244 & 0.441 & -0.055 & 0.085 & 0.074 \\
\hline DPS5 & -0.088 & -0.198 & 0.527 & -0.148 & 0.093 & -0.001 \\
\hline DPS6 & -0.170 & -0.154 & 0.634 & -0.078 & 0.193 & -0.055 \\
\hline PCA1 & -0.044 & -0.087 & -0.028 & 0.172 & -0.021 & 0.163 \\
\hline PCA2 & 0.014 & -0.004 & 0.198 & 0.229 & 0.130 & -0.106 \\
\hline PCA3 & 0.191 & 0.207 & -0.113 & 0.347 & -0.225 & 0.105 \\
\hline PCA4 & 0.514 & 0.217 & -0.083 & 0.929 & -0.214 & -0.037 \\
\hline PCP1 & -0.453 & -0.211 & 0.229 & -0.279 & 0.822 & -0.136 \\
\hline PCP2 & 0.204 & 0.082 & -0.034 & 0.071 & 0.471 & 0.134 \\
\hline PCP3 & -0.164 & -0.168 & 0.320 & -0.070 & 0.512 & -0.136 \\
\hline PCP4 & 0.031 & 0.040 & 0.042 & -0.058 & 0.162 & -0.031 \\
\hline PCP5 & -0.023 & -0.195 & 0.208 & -0.095 & 0.213 & 0.124 \\
\hline PCP6 & -0.066 & -0.112 & 0.243 & -0.063 & 0.197 & 0.038 \\
\hline PCP7 & 0.042 & -0.002 & -0.164 & 0.032 & 0.169 & -0.005 \\
\hline PCP8 & 0.202 & 0.174 & -0.077 & 0.168 & 0.396 & -0.023 \\
\hline PCP9 & -0.125 & -0.166 & 0.208 & -0.012 & 0.397 & 0.011 \\
\hline PU1 & 0.040 & 0.037 & 0.055 & 0.054 & 0.133 & 0.181 \\
\hline PU2 & 0.123 & -0.069 & -0.086 & -0.032 & -0.184 & 0.946 \\
\hline
\end{tabular}

AP Agreeableness Towards Project, DPI Disaster Preparedness Individual Level, DPS Disaster Preparedness State Level, PCA Post Completion Adversities, PCP Post Completion Perception, PU Project Utilization.

METROBUS project itself as well as the prospect development of the similar projects.

To begin with, the locals were found interested in the utilization of the transit service. As $64.5 \%$ of the respondents were found to be the regular users of the service. Moreover, $89.8 \%$ of the respondents were in favor of the fact that METROBUS service was comparatively a safer mode of transportation than the other services operating locally. Thus, deeming the project utilization as a positive contributor towards the agreeableness towards the regarding project. These results are very comparable to the first ever METROBUS project accomplished in Pakistan as well in the city of Lahore. As in the study conducted by Mansoor et al. (2016) \& Zolnik et al. (2018) indicated the fact that the commuters using METRO service in the city preferred the service over the 
Table 7 Instrument's discriminant validity (Heterotrait-Monotrait Ratio)

\begin{tabular}{|c|c|c|c|c|c|c|}
\hline Variables & $\begin{array}{l}\text { Agreeableness } \\
\text { towards project }\end{array}$ & $\begin{array}{l}\text { Disaster preparedness } \\
\text { individual level }\end{array}$ & $\begin{array}{l}\text { Disaster } \\
\text { preparedness } \\
\text { state level }\end{array}$ & $\begin{array}{l}\text { Post completion } \\
\text { adversities }\end{array}$ & $\begin{array}{l}\text { Post completion } \\
\text { perception }\end{array}$ & $\begin{array}{l}\text { Project } \\
\text { utilization }\end{array}$ \\
\hline \multicolumn{7}{|l|}{ Agreeableness Towards Project } \\
\hline $\begin{array}{l}\text { Disaster Preparedness Individual } \\
\text { Level }\end{array}$ & 0.299 & & & & & \\
\hline Disaster Preparedness State Level & 0.811 & 0.516 & & & & \\
\hline Post Completion Adversities & 1.804 & 0.818 & 0.561 & & & \\
\hline Post Completion Perception & 1.303 & 0.732 & 0.736 & 0.666 & & \\
\hline Project Utilization & 0.950 & 0.531 & 0.259 & 0.845 & 0.623 & \\
\hline
\end{tabular}

others because of the sense of safety in social terms as well as the government subsidized fares.

Though in-spite of the project utilization, 79\% respondents depicted critical concerns in regard to the post completion adversities faced due to the project. Referred to which, where on one hand METROBUS service is facilitation to the locals, at the same time, its inauguration disrupted the already established transport business under private-sector management. As $77.6 \%$ of the respondents acknowledged that METROBUS service has turned a significant economic benefit share of the local transportation industry to its favor. The financial impact in the area did not remain limited to the transportation business, but also to the commercial operations that were running in the area for decades. Since the service track passes through the twin cities, its pre-construction stage demanded demolition of some major infrastructure as per the proposed plan as well as extensive excavation at the sites and installation of heavy machinery. Moreover, the project plans didn't take into account the pre-installed underground pipelines (Water and Gas) at certain project locations, historic landmarks and the prospect unfavorable political events. All of which costed the project a time delay of almost 3 months and an incurred loss of $\$ 16.13$ thousand per day (Hussain 2014). For the locals the given situation made it necessary to opt for alternate traffic routes to commute (APP 2014; Hussain 2014). The residents also showed concerns regarding socio-economic and environmental impact of the METROBUS project. The direct inaccessibility of commercial centers to the citizens brought down the economic activities in the area for both the sellers and consumers which is evident from $82.4 \%$ of the respondents' concern during the construction tenure of the METROBUS project causing various business centers to face financial losses. In addition, $55.7 \%$ of the responses conclude that even after completion of the METROBUS project, many businesses either haven't recovered from the losses or have not attained the financial return as it was before. The opinion of the locals is very much reflected in the recent study conducted by (Mansoor et al. 2016) on a specific segment of Rawalpindi-Islamabad METROBUS project which indicated that the regarding project resulted in a decline in economic activities of the businesses nearby. Moreover, $100 \%$ of the respondents residing alongside the track showed their concerns for increased level of noise and air pollution due to the added transport; thus adversely affecting the quality of life (Ali 2015; APP 2015). Thus, attributing the adversities associated to the project as a negative contributor towards the agreeableness towards the current as well as prospect projects. Though, before construction of the similar projects, its potential repercussions on the surrounding environment and related stakeholders are basic consideration to be taken into account. Considering which, international contenders seeking to undertake development projects have been observed to construct sustainable systems that do not affect the residential areas directly and are relatively more eco-friendly than ever (Li et al. 2016; Mojtahedi and Oo 2017; Vuorinen and Martinsuo 2019).

Moving onto the aspect of preparedness towards disaster; seismic in particular, both at state and individual level, were found very low i.e. $34.28 \%$ and $42.34 \%$ respectively. Further at individual level, 59.2\% of the respondents were observed to be directly affected by some major disastrous situation at some point of their lives. Of all the respondents $82.7 \%$ had concerns that given the past occurrences, their locality might get hit with disastrous earthquakes in future while $17.2 \%$ individuals had opinion that floods and other natural calamities might become reason of significant future disruptions in the area. The opinion has been so, because of the previous seismic activities in the region and its associated damages towards infrastructure and locals. Therefore, any more occurrences of such events can lead to higher damages and casualties, as infrastructure in the area under study is mostly not built according to the seismic resistance guidelines. Regardless of the disaster type, $71.4 \%$ of the respondents commented that handling severe injuries would be the primary concern in case of any disaster while $10 \%$ of the respondents suggested epidemic outbreak, $10 \%$ suggested damage to the 
Table 8 Multi-collinearity

\begin{tabular}{|c|c|}
\hline Items & VIF \\
\hline AP1 & 1.011 \\
\hline AP2 & 1.013 \\
\hline AP3 & 1.001 \\
\hline AP4 & 1.004 \\
\hline AP5 & 1.019 \\
\hline DP2 & 1.153 \\
\hline DPI1 & 1.077 \\
\hline DPI2 & 1.085 \\
\hline DPI3 & 1.074 \\
\hline DPI4 & 1.164 \\
\hline DPI5 & 1.148 \\
\hline DPI6 & 1.071 \\
\hline DPI7 & 1.036 \\
\hline DPI8 & 1.079 \\
\hline DPI9 & 1.027 \\
\hline DPS1 & 1.385 \\
\hline DPS3 & 1.345 \\
\hline DPS4 & 1.298 \\
\hline DPS5 & 1.332 \\
\hline DPS6 & 1.092 \\
\hline PCA1 & 1.040 \\
\hline PCA2 & 1.046 \\
\hline РCA3 & 1.036 \\
\hline PCA4 & 1.049 \\
\hline PCP1 & 1.140 \\
\hline PCP2 & 1.097 \\
\hline PCP3 & 1.156 \\
\hline PCP4 & 1.046 \\
\hline PCP5 & 1.231 \\
\hline PCP6 & 1.208 \\
\hline PCP7 & 1.058 \\
\hline PCP8 & 1.048 \\
\hline PCP9 & 1.105 \\
\hline PU1 & 1.022 \\
\hline PU2 & 1.022 \\
\hline
\end{tabular}

AP Agreeableness Towards Project, DPI Disaster Preparedness Individual Level, DPS Disaster Preparedness State Level, PCA Post Completion Adversities, PCP Post Completion Perception, PU Project Utilization.

infrastructure and $8 \%$ showed concern for food supply shortage as a possible outcome of a mismanaged disaster in the twin cities. The magnitude of the mentioned citizen's concerns is directly associated to the seismic events faced in the past decades, and now with the increased population and extensive infrastructure developed over the years, the concern has increased reasonably (Rossetto and Peiris 2009; Shaw 2015). When inquired about the psychological preparedness towards any disastrous situation; seismic in particular, only $26.7 \%$ of the respondents considered themselves prepared to manage the situation. This percentage represents the individuals equipped with the essential citizen disaster science education (CDSE) to some extent. Thus, enabling the regarding individuals with critical information required to survive through seismic hazards, by making educated decisions when faced with any difficulty (Parajuli 2020). In terms of emergency arrangements made, only $25 \%$ of the respondents owned emergency medical supplies that could be helpful to in recovering from the mild wounds. It was commendable to learn that $72 \%$ of the citizens were aware of the healthcare and emergency centers in the vicinity to seek special assistance in case of any seismic disaster. This could assist the effected individuals to seek medical assistance in time, in case they get injured from any infrastructural damage or related cause. Though in terms of post-event psychological effects the citizens were not well aware to manage the situation, as only $33 \%$ of them had local counseling units in their knowledge. This aspect highlighted the fact that locals were possibly less aware of the psychological adversities associated to the undergoing disastrous situation, and therefore unaware of the aid centers designated to manage such cases. Moreover, only $55 \%$ of the citizens were aware of the local administrative authorities and respective aid centers to report to in case of any disaster. In terms of citizenship, $81.2 \%$ of the respondents showed confidence in their fellow citizens to aid them in case any calamity occurs; hence assuring responsible citizenship within the surveyed community.

The prospect disaster management regarding METROBUS project remained questionable with overall, as only $31 \%$ of the respondents showed confidence in the developed project to sustain any disaster situation. This opinion is further backed by few national level reports that indicated infrastructural flaws leading to physical damages to the project caused as result of heavy rains as well as earthquakes of relatively lower magnitude (Ali 2015; Reporter 2015; Reporter 2017; Yasin 2015; Zain 2014). At individual level where citizens showed confidence in their fellow citizens in the hour of need, at the same time, the respondents showed their lack of trust in the national authorities. As only $52.9 \%$ respondents were of the opinion that the government will be able to manage any future disaster situation proactively. In addition, the citizens showed their concerns, as $64.2 \%$ of the respondents opinioned that the national authorities are not adequately equipped with the right provisions to manage a disastrous situation. This opinion is reflected in the shortcomings observed in the past events, in terms of managing the hazardous events, compensating the damages and educating the citizens (Idrees and Khan 2018; Shahbaz 2019). Even in the present study, lack of trust remain constrained to the effective 
Table 9 Factor loadings

\begin{tabular}{|c|c|c|c|c|c|c|}
\hline Items & $\begin{array}{l}\text { Agreeableness } \\
\text { towards project }\end{array}$ & $\begin{array}{l}\text { Disaster preparedness } \\
\text { individual level }\end{array}$ & $\begin{array}{l}\text { Disaster preparedness } \\
\text { state level }\end{array}$ & $\begin{array}{l}\text { Post completion } \\
\text { adversities }\end{array}$ & $\begin{array}{l}\text { Post completion } \\
\text { perception }\end{array}$ & $\begin{array}{l}\text { Project } \\
\text { utilization }\end{array}$ \\
\hline AP1 & 0.704 & & & & & \\
\hline AP2 & 0.721 & & & & & \\
\hline AP3 & 0.778 & & & & & \\
\hline AP4 & 0.706 & & & & & \\
\hline AP5 & 0.930 & & & & & \\
\hline DP2 & & & 0.749 & & & \\
\hline DPI1 & & 0.885 & & & & \\
\hline DPI2 & & 0.824 & & & & \\
\hline DPI3 & & 0.735 & & & & \\
\hline DPI4 & & 0.750 & & & & \\
\hline DPI5 & & 0.935 & & & & \\
\hline DPI6 & & 0.799 & & & & \\
\hline DPI7 & & 0.713 & & & & \\
\hline DPI8 & & 0.714 & & & & \\
\hline DPI9 & & 0.733 & & & & \\
\hline DPS1 & & & 0.728 & & & \\
\hline DPS3 & & & 0.796 & & & \\
\hline DPS4 & & & 0.841 & & & \\
\hline DPS5 & & & 0.727 & & & \\
\hline DPS6 & & & 0.934 & & & \\
\hline PCA1 & & & & 0.772 & & \\
\hline PCA2 & & & & 0.729 & & \\
\hline PCA3 & & & & 0.747 & & \\
\hline PCA4 & & & & 0.729 & & \\
\hline PCP1 & & & & & 0.822 & \\
\hline PCP2 & & & & & 0.771 & \\
\hline PCP3 & & & & & 0.712 & \\
\hline PCP4 & & & & & 0.762 & \\
\hline PCP5 & & & & & 0.913 & \\
\hline PCP6 & & & & & 0.897 & \\
\hline PCP7 & & & & & 0.869 & \\
\hline PCP8 & & & & & 0.996 & \\
\hline PCP9 & & & & & 0.997 & \\
\hline PU1 & & & & & & 0.881 \\
\hline PU2 & & & & & & 0.946 \\
\hline
\end{tabular}

AP Agreeableness Towards Project, DPI Disaster Preparedness Individual Level, DPS Disaster Preparedness State Level, PCA Post Completion Adversities, $P C P$ Post Completion Perception, $P U$ Project Utilization.

Table 10 Path coefficients

\begin{tabular}{|c|c|c|c|}
\hline & Original sample (0) & $\begin{array}{l}\text { T statistics } \\
(\mid \text { O/STDEV|) }\end{array}$ & $P$ Values \\
\hline Disaster Preparedness Individual Level > Agreeableness Towards Project & -0.167 & 8.027 & 0.000 \\
\hline Disaster Preparedness State Level > Agreeableness Towards Project & -0.118 & 9.393 & 0.000 \\
\hline Post Completion Adversities > Agreeableness Towards Project & -0.424 & 9.391 & 0.000 \\
\hline Post Completion Perception > Agreeableness Towards Project & -0.290 & 2.011 & 0.012 \\
\hline Project Utilization > Agreeableness Towards Project & 0.109 & 2.341 & 0.020 \\
\hline
\end{tabular}


Table 11 Effect size $\left(f^{2}\right)$

\begin{tabular}{|c|c|c|c|c|c|c|}
\hline & $\begin{array}{l}\text { Agreeableness } \\
\text { towards project }\end{array}$ & $\begin{array}{l}\text { Disaster preparedness } \\
\text { individual level }\end{array}$ & $\begin{array}{l}\text { Disaster } \\
\text { preparedness } \\
\text { state level }\end{array}$ & $\begin{array}{l}\text { Post completion } \\
\text { adversities }\end{array}$ & $\begin{array}{l}\text { Post completion } \\
\text { perception }\end{array}$ & $\begin{array}{l}\text { Project } \\
\text { utilization }\end{array}$ \\
\hline \multicolumn{7}{|l|}{ Agreeableness Towards Project } \\
\hline $\begin{array}{l}\text { Disaster Preparedness Individual } \\
\text { Level }\end{array}$ & 0.043 & & & & & \\
\hline Disaster Preparedness State Level & 0.116 & & & & & \\
\hline Post Completion Adversities & 0.288 & & & & & \\
\hline Post Completion Perception & 0.122 & & & & & \\
\hline Project Utilization & 0.021 & & & & & \\
\hline
\end{tabular}

management of the event itself and also to the post-event management of the situation. About $63.9 \%$ respondents in light of past occurrences stated that the national authorities didn't compensate the locals for their losses. Thus, leaving the citizens in dismay and in most cases, they became victimized by the poverty or down-scaled level of economic stability. Moreover, $74.7 \%$ respondents stated that they were not provided with the self-help learning material and training to get through a calamity. Even the $25.3 \%$ of the respondents who got provided with the mentioned learning material and training beforehand, too showed their dissatisfaction towards the effectiveness of the provisions. Thus, $74.7 \%$ of them held unfavorable opinion.

Given the situation, the overall preparedness towards disaster situation at both the individual as well as state level were found to have significant amount of room for improvements to make the project sustainable for times to come. This opinion has been found in the related studies as well, suggesting the lack of disaster management policies and their respective implementation in absolute manner (Mojtahedi and Oo 2017; Reporter 2017). Thus, depicting overall disaster preparedness as a negative contributor towards the afore mentioned agreeableness. Keeping that in view, the need to enhance disaster risk reduction (DRR) coupled with the effective dissemination of citizen disaster science education (CDSE) has been highlighted in various studies conducted in regions sharing similar circumstance as Pakistan, and is therefore need of time in the country as well (Parajuli 2020; Tuladhar et al. 2015).

Akin to the concurrent disaster preparedness situation, the perception regarding METROBUS project remained questionable as well. As $55 \%$ of the citizens responded that the project development wasn't carried out while taking the proposed ethical work guidelines into account in an absolute manner. This further led to the

Table 12 Coefficient of determination

\begin{tabular}{lcc}
\hline & R square & R square adjusted \\
\hline Agreeableness Towards Project & 0.452 & 0.444 \\
\hline
\end{tabular}

inconveniences faced by the locals to carry out their daily life activities (Hussain 2014; Yasin 2015). Moreover, after the operation of the project, heavy weather conditions caused certain deteriorative changes in the project and brought out the visible flaws (Ali 2015; Yasin 2015; Zain 2014), which further assured the locals that in case of a higher magnitude disaster, the project won't be able to withstand the odds with about $74.1 \%$ of the respondents in favor of this opinion. In the current circumstances, the citizens were more concerned about the future because of the fact that the project incurred various damages soon after it was set in operation for the very first time. This raised significant level of concerns in terms of project's inspection and safety being followed (Editorial 2014; Hasan 2014; Reporter 2015; Reporter 2017; Zain 2014). Referred to this $53.5 \%$ of the respondents suggested that inspection and safety should be the primary concern of local appointed authorities for the sustainability of the project as well as the safety of the surrounding infrastructure. As most of the responses were collected from the occupants of residential and commercial property alongside the project, the results revealed the fact that $55.6 \%$ of the respondents considered themselves as primary affectees of the project's damage in case any disaster occurs. In addition, almost $83.6 \%$ of the respondents agreed to the fact that commercial infrastructure too will come under direct impact in case damage occurs to the project itself. In reference to this, $87.2 \%$ of the respondents were of the opinion that the business activities will get highly disrupted in case of any disaster thus, leaving the citizens with short amount of supplies to get through any disastrous situation at their own. Keeping this in view, $68.4 \%$ of respondents showed their concern that there are very less chances for the economic activities to be resumed in time. This will not only increase the chances of casualties but also put adverse impact in terms of local economic stability. Regarding disaster and damaged infrastructure, $69.9 \%$ of the respondents were of opinion that in case any section of the METROBUS track collapses, it will increase the chances of casualties as track runs through the busiest 
Table 13 Results summary

\begin{tabular}{lll}
\hline Index & Hypothesis & Result \\
\hline H1 & Disaster Preparedness (Individual Level) will significantly impact the Agreeableness Towards Project. & Accepted \\
H2 & Disaster Preparedness (State Level) will significantly impact the Agreeableness Towards Project. & Accepted \\
H3 & Post Completion Adversities will significantly impact the Agreeableness Towards Project. & Accepted \\
H4 & Post Completion Perception will significantly impact the Agreeableness Towards Project. & Accepted \\
H5 & Project Utilization will significantly impact the Agreeableness Towards Project. & Accepted \\
\hline
\end{tabular}

routes of the city for the most part and in case of major damage to any section, possible routes to the emergency facilities and hospitals nearby will get blocked. Thus, leaving the prospect affectees stranded until special aid arrives or alternate routes are cleared.

Lastly, due to the lack of preparedness on both the individual as well as at the state level, the overall acceptance towards the project turned out very low i.e. $34.68 \%$. Referred to which, the project-based perception proved itself significantly to be a negative contributor towards the overall agreeableness of the project.

As far as the acceptability of the METROBUS projected by the residents is concerned, almost $68.7 \%$ opinioned against the project due to various reasons but most importantly the lack of trust in the national authorities. Almost $67.5 \%$ of the respondents believed that the purpose of the project was only to attain political gains; whereas only $13.3 \%$ held opinion that the purpose of the project was social welfare. The local residents and traders faced significant inconveniences during the project's construction as well as after its operation (APP 2014; APP 2015; Editorial 2014; Hussain 2014; Yasin 2015). This is another reason for the locals to vote against the project. The mentioned concerns of the respondents highlight the importance of taking into account the convenience of the locals as well as enriching the environment before taking on any developmental endeavors (Aaltonen and Kujala 2010; Lin et al. 2017; Nguyen et al. 2018) The project focused in the current study is second of its kind in Pakistan, and its preceding project developed in Lahore has been attributed with similar societal and technical concerns (Mansoor et al. 2016). Considering the common concerns between both projects, it is necessary to highlight the criticality of considering the locals as potential stakeholders associated to any developmental project in any given society. It is strongly suggested by $78.5 \%$ of the respondents that the national authorities should involve the locals being the stakeholders at some level in the process of project's feasibility and planning. Another major reason of the lack of trust in the national authorities is the fact that there have been no significant improvements in the project even after the flaws were identified throughout the operational tenure of the project. Almost $61 \%$ of the respondents were of the opinion that responsible authorities made no significant changes over time in the project to improve its safety and quality standards, and this opinion resonated with several reports compiled on the said project (Ali 2015; Yasin 2015; Zain 2014). To bring about these changes $68.4 \%$ of the respondents were of point of view that only national authorities are responsible for making related changes while $27.3 \%$ believed that local community members should contribute on their own to resolve the concurrent situation and to bring about improvements in the project. Only $4.1 \%$ of the respondents were of the opinion that NGOs can be of some benefit towards the situation. Lastly, due to quality service provided to the locals on one hand and the adversities faced due to the project with added lack of faith in national authorities on the other hand, the opinion for prospect projects was a total split with about $50 \%$ of the locals in favor of development of projects such as METROBUS project in the locality and surroundings in the future, while $50 \%$ of respondents were against it.

\section{Conclusion}

The findings of the study led to various provocative deductions regarding socio-economic perception of the METROBUS project as well as the associated disaster management measures. Though the associated hindrance faced by the locals (Residents or Businessmen) in both the pre and post-development of the project is concluded as an undisputed opinion. Regardless, the citizens were in favor of the service quality being offered by the project as most of the locals were utilizing it. In terms of the seismic disaster management measures attributed to the METROBUS project, it was deterring to discover the fact that while most of the respondents were educated ones, yet their preparedness towards potential emergency situations caused by prospect seismic hazard to the METROBUS project was questionable. It was encouraging to know that most of the respondents were aware of the local services to reach in the case of emergency for aid in critical situations. In terms of dependency, the citizens held faith more in the fellow community members than the national authorities. Moreover, the locals showed significant concerns in regard to the national authorities to manage the situation of crisis effectively and efficiently. It was concluded that the national authorities did not prove themselves to 
be effective to educate and support the citizens regarding disastrous situations. Specific to the METROBUS project, the citizens had doubts regarding its safety against calamities of higher magnitude, given the deterioration observed in the past. Majority of public has rated METROBUS project as a government-oriented project than a welfare one.

Thus, the citizens for most part had a negatively inclined opinion towards the project or even the development of similar prospect projects in the region. Based upon the results, it is also concluded that the development of welfare-oriented projects must take into account the opinion of all of its stakeholders i.e. the residents or the common people, during the complete life cycle of any infrastructural project. As it will increase the goodwill of the locals towards the respective organizations (private/public) and may even bring into consideration the factors that might have got overlooked by the entities initiating the infrastructural development. Since the solution imposed are not always appreciable as they face community reaction based on implications later due to improper planning and development. This is needed to be learned by the middle-low income countries for the betterment of the society. Current study provides policy makers an in-depth perspective of the stakeholders involved in similar megaprojects and will results in the development of efficient and effective policies accordingly for Pakistan and other developing countries.

\section{Acknowledgements}

We would like to extent our thanks to the citizens of the twin cities who graciously participated in the data collection process and made this research a reality.

\section{Conflict of interest}

There is no conflict of interest.

\section{Authors' contributions}

All the author contributed in the accomplishment of the manuscript and its refinement. The author(s) read and approved the final manuscript.

\section{Funding}

This manuscript was not funded by any organization.

\section{Availability of data and materials}

All the data and materials used are mentioned in the article.

\section{Competing interests}

Current manuscript has no competing interest between any parties.

\author{
Author details \\ IInterdisciplinary Research Center, COMSATS University Islamabad, Wah \\ Cantt, Pakistan. ${ }^{2}$ Department of Mechanical Engineering, COMSATS University \\ Islamabad, Wah Cantt, Pakistan. ${ }^{3}$ Department of Management Science, \\ COMSATS Institute of Information Technology, Wah Cantt, Pakistan. \\ ${ }^{4}$ Department of Civil Engineering, COMSATS Institute of Information \\ Technology, Wah Cantt, Pakistan. ${ }^{5}$ Department of Environmental Sciences, \\ Quaid-i-Azam University, Islamabad, Pakistan.
}

Received: 19 July 2019 Accepted: 4 November 2020

Published online: 10 November 2020

\section{References}

Aaltonen K, Kujala J (2010) A project lifecycle perspective on stakeholder influence strategies in global projects. Scand J Manag 26:381-397

Ab Hamid M, Sami W, Sidek MM (2017) Discriminant validity assessment: use of Fornell \& Larcker criterion versus HTMT criterion. In: Journal of Physics: Conference Series, vol 1. IOP Publishing, p 012163

Afthanorhan A, Awang Z, Mamat M (2016) A comparative study between GSCASEM and PLS-SEM MJ. J Stat Probability 1:63-72

Afthanorhan W (2013) A comparison of partial least square structural equation modeling (PLS-SEM) and covariance based structural equation modeling (CB-SEM) for confirmatory factor analysis. Int J Eng Sci Innovative Technol 2:198-205

Ahmed ZN (2018) Timeline of major earthquakes in Pakistan: 1971-2018, January 31, 2018 edn. Dawn, Pakistan

Akbar A (2016) Six killed as 7.1 magnitude quake jolts northern areas, Punjab, April 10, 2016 edn. Dawn, Pakistan

Ali F (2015) Metro project: Labourers face risks, health hazards and exploitation, January 2, 2015 edn. The Express, Pakistan

APP (2014) Alternative traffic routes plan for Pindi, march 27, 2014 edn. Dawn, Pakistan

APP (2015) Metro bus project: pollution, traffic mess a 'gift' for residents, January 26, 2015 edn. The Express, Pakistan

Awang Z, Afthanorhan A, Mamat M (2016) The Likert scale analysis using parametric based Structural Equation Modeling (SEM). Comput Methods Soc Sci 4:13

BiBi H, Yasmeen S, Chaudhry AG, Hadi SA (2015) Effects of mega metro project on Rawalpindi's socio-economic and cultural life

Blaikie P, Cannon T, Davis I, Wisner B (2014) At risk: natural hazards, people's vulnerability and disasters. Routledge

Busby J, Smith TG, Krishnan N, Wight C, Vallejo-Gutierrez S (2018) In harm's way: Climate security vulnerability in Asia. World Dev 112:88-118

Cable DM, DeRue DS (2002) The convergent and discriminant validity of subjective fit perceptions. J Appl Psychol 87:875

Center GD (2017) World data service (NGDC/WDS). https://doi.org/10.7289/ V5TD9V7K

Debarati Guha-Sapir PH, Wallemaca P, Below R (2017) Annual disaster statistical review 2016: the numbers and trends. Centre for Research on the Epidemiology of Disasters

Desk AW (2015) Metro bus project: this is the dawn of a new era, says PM Nawaz, June 4, 2015 edn. The ExpressTribune, Pakistan

Di Bucchianico A (2008) Coefficient of determination (R2) encyclopedia of statistics in quality and reliability

Durrani AJ, Elnashai AS, Hashash Y, Kim SJ, Masud A (2005) The Kashmir earthquake of October 8, 2005: A quick look report MAE Center CD Release 05-04

Editorial (2014) Punjab under water, September 6, 2014 edn. The Express, Pakistan

Fornell C, Larcker DF (1981) Evaluating structural equation models with unobservable variables and measurement error. J Mark Res:39-50

Gliem JA, Gliem RR (2003) Calculating, interpreting, and reporting Cronbach's alpha reliability coefficient for Likert-type scales. In: Midwest research-topractice conference in adult, continuing, and community education

Guha-Sapir D, Hargitt D, Hoyois P (2004) Thirty years of natural disasters 19742003: the numbers. Presses univ. de Louvain

Guha-Sapir D, Ph H (2015) Annual disaster statistical review 2014: the numbers and trends

Guha-Sapir D, Vos F, Below R, Ponserre S (2012) Annual disaster statistical review 2011: the numbers and trends. Centre for Research on the Epidemiology of Disasters (CRED)

Hair JF, Ringle CM, Sarstedt M (2011) PLS-SEM: Indeed a silver bullet. J Mark Theory Pract 19:139-152

Hair JF Jr, Hult GTM, Ringle C, Sarstedt M (2016) A primer on partial least squares structural equation modeling (PLS-SEM). Sage Publications

Hasan A (2014) Just how 'Fit for Purpose' are the Metrobus projects?, October 07, 2014 edn. Dawn, Pakistan

Hox JJ, Moerbeek M, van de Schoot R (2017) Multilevel analysis: techniques and applications. Routledge

Hussain D (2014) Metro bus completion: delay to cost Punjab, centre Rs2.6 million per day, November 16, 2014 edn. The Express, Pakistan 
Idrees MW, Khan MB (2018) Analysis of susceptibilities, capacities of local communities, disaster management structures, policies and institutions in pakistan: a case of Azad Jammu and Kashmir (AJK). Rev Econ Dev Stud 4: 189-197

Jonkman SN (2005) Global perspectives on loss of human life caused by floods. Nat Hazards 34:151-175

Kaneda $\mathrm{H}$ et al (2008) Surface rupture of the 2005 Kashmir, Pakistan, earthquake and its active tectonic implications. Bull Seismol Soc Am 98:521-557

Keim ME (2008) Building human resilience: the role of public health preparedness and response as an adaptation to climate change. Am J Prev Med 35:508-516

Khan AN (2010) Chapter 10 Climate change adaptation and disaster risk reduction in Pakistan' Climate Change Adaptation and Disaster Risk Reduction: An Asian Perspective (Community, Environment and Disaster Risk Management, Volume 5). Emerald Group Publishing Limited, pp 197-215

Khan H, Khan A (2008) Natural hazards and disaster management in Pakistan Kirsch TD, Wadhwani C, Sauer L, Doocy S, Catlett C (2012) Impact of the 2010 Pakistan floods on rural and urban populations at six months. PLoS Curr:4 Korver AJ (1986) What is a disaster? Prehosp Disaster Med 2:152-153

Lane SP, Hennes EP (2018) Power struggles: Estimating sample size for multilevel relationships research. J Soc Pers Relat 35:7-31

Li TH, Thomas Ng S, Skitmore M (2016) Modeling multi-stakeholder multiobjective decisions during public participation in major infrastructure and construction projects: A decision rule approach. J Constr Eng Manag 142: 04015087

Lim SK, Yang J (2008) Understanding the need of project stakeholders for improving sustainability outcomes in infrastructure projects. In: Proceedings of the Performance and Knowledge Management Joint CIB Conference, pp 332-343

Lin X, Ho CM, Shen GQ (2017) Who should take the responsibility? Stakeholders' power over social responsibility issues in construction projects. J Clean Prod 154:318-329

Mansoor A, Zahid I, Shahzad L (2016) Evaluation of social and environmental aspects of Lahore Metro Bus Transit through public opinion. J Environ Sci Manag:19

Mojtahedi M, Oo BL (2017) The impact of stakeholder attributes on performance of disaster recovery projects: the case of transport infrastructure. Int J Proj Manag 35:841-852

Montz BE, Tobin GA, Hagelman RR (2017) Natural hazards: explanation and integration. Guilford Publications

Nguyen THD, Chileshe N, Rameezdeen R (2018) External stakeholder strategic actions in construction projects: a Vietnamese study. Constr Manag Econ 36: 443-458

Pakistan Go (2014) Pakistan Metrobus System. http://www.pma.punjab.gov.pk Pakistan Go (2017) Federal Budget 2017-18: Budget in Brief vol 1

Parajuli RR (2020) Citizen Disaster Science Education for effective disaster risk reduction in developing countries. Geoenvironmental Disasters 7:1-4

Paton D, Johnston D (2017) Disaster resilience: an integrated approach. Charles C Thomas Publisher

Perry RW (2007) What is a disaster? Handb Disaster Res:1-15

Plane DA (2017) The sustainability of demographic progress around the world. In: Socioeconomic environmental policies and evaluations in regional science. Springer, pp 9-36

Razzaq A, Thaheem MJ, Maqsoom A, Gabriel HF (2018) Critical external risks in international joint ventures for construction industry in Pakistan. Int J Civ Eng 16:189-205

Reporter A (2015) Rainwater enters metro bus stations, June 25, 2015 edn. Dawn, Pakistan

Reporter A (2017) RDA estimates Rs26m worth of damages to Faizabad metro bus station, December 05, 2017 edn. Dawn, Pakistan

Ringle C, Wende S, Becker J (2017) SmartPLS—statistical software for structural equation modeling

Rossetto T, Peiris N (2009) Observations of damage due to the Kashmir earthquake of October 8, 2005 and study of current seismic provisions for buildings in Pakistan. Bull Earthq Eng 7:681-699

Sana H, Nath SK, Gujral KS (2019) Site response analysis of the Kashmir valley during the 8 October 2005 Kashmir earthquake (M w 7.6) using a geotechnical dataset. Bull Eng Geol Environ 78:2551-2563

Sasoli I (2017) 6.3 earthquake jolts parts of Balochistan, February 08, 2017 edn. Dawn, Pakistan
Shahbaz S (2019) Disaster preparedness and management in Pakistan: a systematic review. Prehosp Disaster Med 34:s122-s122

Shaw R (2015) Hazard, vulnerability and risk: the Pakistan context. In: Disaster risk reduction approaches in Pakistan. Springer, pp 31-52

Smith K (2013) Environmental hazards: assessing risk and reducing disaster. Routledge

Syed Ali Shah HB, Sasoli I, Sirajuddin, Bacha U (2018) Quake tremors jolt various parts of Pakistan, 1 girl killed, January 31, 2018 edn. Dawn, Pakistan

Toh YZ, Goh YM, Guo BH (2017) Knowledge, attitude, and practice of design for safety: multiple stakeholders in the Singapore construction industry. J Constr Eng Manag 143:04016131

Tuladhar G, Yatabe R, Dahal RK, Bhandary NP (2015) Disaster risk reduction knowledge of local people in Nepal. Geoenvironmental Disasters 2:1-12

UNISDR C (2015) The human cost of natural disasters: A global perspective.

Vuorinen L, Martinsuo M (2019) Value-oriented stakeholder influence on infrastructure projects. Int J Proj Manag 37:750-766

Wahlstrom M, Guha-Sapir D (2015) The human cost of weather-related disasters 1995-2015. United Nations International Strategy for Disaster Reduction, Geneva

Williams SO, Hamid RA, Misnan MS, Ogunbode BA (2018) Management of construction safety: the failure and success of stakeholders. Int I Acad Res Bus Soc Sci 8

Wong KK-K (2013) Partial least squares structural equation modeling (PLS-SEM) techniques using SmartPLS. Mark Bull 24:1-32

Yasin A (2015) Repair of metro bus track worsens traffic woes, November 02, 2015 edn. Dawn, Pakistan

Zaafir MS (2017) PM for expediting work on metro bus project, December 5 , 2017 edn. The News, Pakistan

Zain A (2014) Stone falling from 'deteriorating' metro bridge kills a man in Rawalpindi. Pakistan Daily, Pakistan

Zolnik EJ, Malik A, Irvin-Erickson Y (2018) Who benefits from bus rapid transit? Evidence from the Metro Bus System (MBS) in Lahore. J Transp Geogr 71: 139-149

\section{Publisher's Note}

Springer Nature remains neutral with regard to jurisdictional claims in published maps and institutional affiliations.

\section{Submit your manuscript to a SpringerOpen ${ }^{\odot}$ journal and benefit from:}

- Convenient online submission

- Rigorous peer review

- Open access: articles freely available online

- High visibility within the field

- Retaining the copyright to your article

Submit your next manuscript at $>$ springeropen.com 